\title{
Regulation by cytokines of the inducible nitric oxide synthase promoter in insulin-producing cells
}

\author{
M. I. Darville, D. L. Eizirik \\ Diabetes Research Center, Vrije Universiteit Brussel, Brussels, Belgium
}

Summary Cytokines could contribute to beta-cell damage in Type I diabetes mellitus. The radical nitric oxide, generated by the inducible form of nitric oxide synthase (iNOS), is a potential mediator of cytokineinduced beta-cell dysfunction. In rat pancreatic islets and insulin-producing cell lines, interleukin- $1 \beta$ (IL$1 \beta$ ) induces expression of iNOS mRNA and increases NO production, an effect potentiated by interferon- $\gamma$ $($ IFN- $\gamma)$. In human islet cells both IL- $1 \beta$ and IFN- $\gamma$ are required for iNOS expression. We have shown previously that both the transcription factors nuclear factor- $\kappa \mathrm{B}(\mathrm{NF}-\kappa \mathrm{B})$ and interferon regulatory factor1 (IRF-1) are activated by cytokines in rodent and human islets but there is no direct information on the regulation of the iNOS promoter in insulin-producing cells. We presently investigated the effects of cytokines on iNOS transcriptional regulation in both rat insulin-producing RINm5F cells and in primary FACS-purified rat beta cells. Transient transfection experiments with the $1.5-\mathrm{kb}$ rat promoter region and 5 ' deletants of it showed that a distal region extending up to $-1002 \mathrm{bp}$, and containing a distal and a proximal nuclear factor- $\kappa \mathrm{B}(\mathrm{NF}-\kappa \mathrm{B})$ binding site, a $\gamma$-interferon activated site (GAS) and two adjacent IFNstimulated response elements (ISRE), is required for
IL- $1 \beta$ induction and IFN- $\gamma$ potentiation of iNOS activation. Site-mutation analysis showed that both the distal and proximal $\mathrm{NF}-\kappa \mathrm{B}$ and GAS are necessary for IL- $1 \beta$-induced iNOS expression in RINm5F cells. In these cells IFN- $\gamma$ potentiation is mostly mediated by GAS and ISRE, suggesting a role for the IFN- $\gamma$-induced transcription factors Stat $1 \alpha$ (which binds GAS) and IRF-1 (which binds ISRE), which may cooperate with NF- $\kappa \mathrm{B}$ induced by IL- $1 \beta$ for iNOS activation. In primary beta cells both $\mathrm{NF}-\kappa \mathrm{B}$ binding sites are required for IL- $1 \beta$-induced iNOS promoter activation. In these cells IFN- $\gamma$ neither increased IL- $1 \beta$ induced iNOS promoter activity nor iNOS mRNA expression but it induced a twofold increase in NO production. The present results unveiled the nature of the promoter binding sites necessary for iNOS expression in rodent beta cells. This information could be relevant for the development of new strategies aimed at preventing cytokine-induced iNOS expression and consequent beta-cell damage. [Diabetologia (1998) 41: 1101-1108]

Keywords Nitric oxide, iNOS, NF- $\kappa B$, beta-cells, interleukin-1, diabetes mellitus.
Rneceived: 2 March 1998 and in revised form: 22 April 1998

Corresponding author: Dr Décio L. Eizirik, Diabetes Research Center, Vrije Universiteit Brussel, Laarbeeklaan 103, B-1090 Brussel, Belgium

Abbreviations: FACS, fluorescence activated cell sorting; IFN$\gamma$, interferon- $\gamma$; IL- $1 \beta$, interleukin- $1 \beta$; TNF- $\alpha$, tumour necrosis factor- $\alpha$; iNOS, inducible form of nitric oxide synthase; LPS, lipopolysaccharide; GAS, $\gamma$-interferon activated site; ISRE, IFN-stimulated response element; IRF-1, interferon regulatory factor-1; NF- $\kappa \mathrm{B}$, nuclear factor $\kappa$ beta; RT-PCR, reverse transcriptase polymerase chain reaction; NO, nitric oxide; IBMX, 3-isobutyl-1-methylxanthine; GAPDH, glyceraldehyde 3phosphate dehydrogenase; ANOVA, analysis of variance.
Type I (insulin-dependent) diabetes mellitus results from a selective destruction of the pancreatic insulin-producing beta cells. Cytokines, especially interleukin-1 $\beta$ (IL-1 $\beta$ ), could play an important role in immune-induced beta-cell damage $[1,2]$. Several of the deleterious effects of cytokines on rodent islets are mediated by the radical nitric oxide (NO), produced by the inducible form of nitric oxide synthase (iNOS) [3-5]. Involvement of NO in beta cell degeneration has also been shown in vivo in transgenic mice overexpressing iNOS under the control of the insulin promoter [6]. In human islets, combinations 
of cytokines also induce iNOS expression $[7,8]$ but in these cells cytokine-induced dysfunction and death by apoptosis occurs even when iNOS expression is prevented by specific blockers [8-10]. On the other hand, exposure of human islets to higher levels of NO or peroxynitrite (a product of the reaction between NO and superoxide) leads to DNA strand breaks and beta cell death $[10,11]$.

In rat islets IL- $1 \beta$, alone or in combination with interferon- $\gamma$ (IFN- $\gamma)$ or tumour necrosis factor- $\alpha$ (TNF- $\alpha$ ) or both, induces the expression of iNOS, whereas human islets express iNOS only after exposure to a combination of two (IL- $1 \beta+$ IFN- $\gamma$ ) or three (IL- $1 \beta+$ IFN- $\gamma+$ TNF- $\alpha$ ) cytokines [12]. Following stimulation by different proinflammatory cytokines and endotoxins, iNOS is also induced in various cell types including: macrophages, vascular smooth muscle cells, mesangial cells, hepatocytes and astrocytes [13]. It is noteworthy that there are large variations in the regulation of iNOS expression when comparing both different cell types from the same species, or cells isolated from different species. Thus, although in mouse macrophages iNOS is induced by lipopolysaccharide (LPS) or IFN- $\gamma$ or both, in rat and mouse beta cells iNOS is induced by IL- $1 \beta$ alone, but not by IFN- $\gamma$ or LPS or both [12]. At least part of this differential regulation may be explained by differences in activation of transcription factors and usage of different binding sites at the promoter level.

The mouse and rat iNOS promoters have been characterized and shown to contain two regions with DNA-binding elements for different transcription factors $[14,15]$. The proximal region contains a NF$\kappa \mathrm{B}$ site necessary for conferring inducibility to LPS in macrophages [16]. The distal region contains both a second NF- $\mathrm{KB}$ site, a $\gamma$-interferon activated site (GAS) and two adjacent IFN-stimulated response elements (ISREs), and it is essential for both optimal iNOS induction by LPS, for the synergistic effect of IFN- $\gamma$ in mouse macrophages and for iNOS induction by cytokines in rat vascular smooth muscle cells $[14$, 16-18]. Besides the NF- $\mathrm{KB}$ binding sites described above, mutagenesis studies have shown that other sites of relevance for cytokine-induced iNOS expression include GAS (which binds Stat1 $\alpha$; [19]) and ISRE (which binds IRF-1; [20, 21]). IRF-1 is probably essential for iNOS activation in macrophages, since macrophages obtained from knockout mice for the IRF-1 gene fail to express iNOS [22]. Available data from rodent and human pancreatic islets suggest that both NF- $\mathrm{NB}$ [23-26] and IRF-1 [27, 28] may play a role for iNOS expression. This hypothesis is, however, mostly based on the observation of transcription factor activation upon cytokine exposure, and there is no direct evidence for the involvement of specific components of the iNOS promoter in the response of insulin-producing cells to cytokines.
In order to characterize the regulation of iNOS expression in insulin-producing cells, we analysed the effects of three cytokines (IL- $1 \beta$, IFN- $\gamma$ and TNF- $\alpha$ ) on rat iNOS promoter activity in an insulin-producing cell line, RINm5F, and in primary FACS-purified rat beta cells. This was done by cell transfection with deleted constructs of the iNOS promoter region and by site-directed mutagenesis of specific binding sites for transcription factors present in the iNOS promoter.

\section{Materials and methods}

Cell culture. RINm5F insulinoma cells were cultured in RPMI 1640 medium with Glutamax-1 (Life Technologies, Paisley, Scotland) supplemented with $10 \%$ fetal calf serum. Rat beta and alpha cells were purified from islets isolated from male Wistar rats as described previously [29]. Briefly, pancreatic islets were isolated from adult male Wistar rats by collagenase digestion. Fresh islets were dissociated and purified by fluorescence-activated cell sorting (FACS) into cell preparations containing either more than $95 \%$ beta cells or more than $80 \%$ alpha cells. Cells were cultured in HAM's F-10 medium supplemented with $10 \mathrm{mmol} / 1$ glucose, $2 \mathrm{mmol} / \mathrm{l}$ glutamine, $0.5 \%$ bovine serum albumin and $50 \mu \mathrm{mol} / 13$-isobutyl-1-methylxanthine (IBMX). The presence of IBMX at this concentration preserves beta-cell survival in culture [30] with minimal effects on cyclic AMP formation in the absence of adenylate cyclase activators [31].

Cloning of the iNOS promoter region. Rat genomic DNA was prepared from liver as described [32]. The iNOS promoter region between nucleotides -1514 and +132 was amplified by PCR on $0.5 \mu \mathrm{g}$ genomic DNA using the Expand High Fidelity PCR system (Boehringer Mannheim, Mannheim, Germany) according to the manufacturer's instructions and using two primers based on the published sequence [15]. The forward primer was 5'-CGGAATTCTGACCAGCAAAACCCAGG with an added EcoRI site and the reverse primer was $5^{\prime}$ CGGGATCCGACTAGGCTAACAAGACC with an added BamHI site. The amplified product was cloned in pBluescript KS- (Stratagene, La Jolla, Calif., USA) and sequenced using an ABI PRISM Dye Terminator Cycle Sequencing kit on an ABI PRISM 310 Genetic Analyzer (Perkin Elmer, Norwelk, Conn., USA).

Plasmid constructions and mutagenesis. The promoter region $(-1514$ to +132$)$ and its $5^{\prime}$ deleted fragments were isolated from pBluescript by digesting with BamHI ( $3^{\prime}$ end) and the following restriction enzymes for the $5^{\prime}$ end: EcoRV (-1514), NcoI filled in with Klenow fragment of DNA polymerase I (-1002), SspI (-916) or PvuII (-315). The fragments were cloned upstream of the luciferase reporter gene of pGL3-Basic (Promega, Madison, Wis., USA) in the SmaI-BglII sites to obtain the piNOSluc constructs, with the exception of the $S s p$ IBamHI fragment which was first recloned in the EcoRV-BamHI sites of pBluescript. The fragment was then isolated by digestion with HindIII filled in with the Klenow fragment of DNA polymerase I and with BamHI, and cloned into pGL3Basic to obtain piNOS-918luc. This allowed preservation of the border bases of the distal ISRE.

Mutations in the GAS, distal ISRE and proximal NF- $\kappa B$ site were generated in the piNOS-1002luc construct by site-directed mutagenesis using the U.S.E. Mutagenesis kit (Phar- 


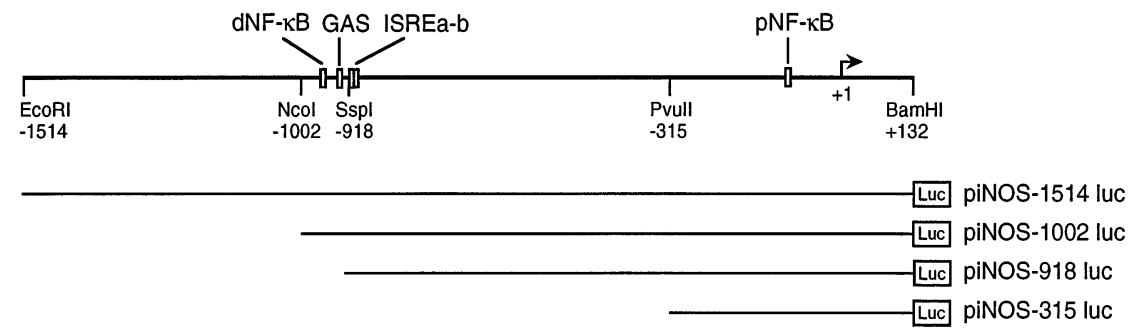

Fig. 1. Schematic representation of the rat iNOS promoter. The broken arrow indicates the transcription start site. Binding sites for transcription factors are indicated by boxes. $\mathrm{dNF}-\kappa \mathrm{B}$ and $\mathrm{pNF}-\kappa \mathrm{B}$ indicate respectively, distal and proximal NF- $\kappa \mathrm{B}$ binding sites. The promoter region and $5^{\prime}$ deletants thereof cloned upstream of the luciferase reporter gene are indicated in the lower part of the figure

macia, Uppsala, Sweden) according to the manufacturer's instructions. The mutagenic primers (mutated bases underlined) were as follows: GASmut (5'-GTTTGTTCCTTTGCCCCTACTACTGTCAATATTTC), ISREmut (5'-CTGTCAATATGTAAACTTTCATAATGG) and pNFmut (5'-CACACCCTACTGCAGTCTCTCCCTTTGG). Mutation in the distal NF- $\kappa \mathrm{B}$ site was generated by run-around PCR [33] using the Expand high fidelity PCR system, the forward primer dNFmut (5'-GGATATGCCAGGCCTATTTTCCCTCTC) and the reverse primer (5'-CGCCAGGGTCCACTCATCATCC). All mutations were confirmed by sequencing.

Transfections and luciferase assay. Cells were transfected by lipofection with lipofectAMINE (Life Technologies, Gaithersburg, Md., USA) according to the manufacturer's instructions. Cells were seeded $24 \mathrm{~h}$ before transfection at $6.10^{4}$ cells (RINm5F cells) or $10^{5}$ cells (alpha and beta cells) in 24-well plates. For primary cells, poly-D-lysine $(100 \mu \mathrm{g} / \mathrm{ml})$-coated plates were used. The DNA-lipid mixture contained $0.2 \mu \mathrm{g}$ of test plasmid, 0.01 or $0.02 \mu \mathrm{g}$ of pRL-CMV (Promega) as internal control and $2 \mu \mathrm{l}$ (RINm5F cells) or $1 \mu \mathrm{l}$ (alpha and beta cells) of lipofectAMINE. Cells were exposed to the DNA-lipid complex for $5 \mathrm{~h}$, at which time the complex was removed and replaced by culture medium for 18-24 h. At this point, medium was changed and recombinant human IL-1 $\beta$ (30 U/ml; kindly provided by Dr C.W. Reynolds, National Cancer Institute, USA), recombinant murine IFN- $\gamma$ (1000 U/ml; Holland Biotechnology, Leiden, The Netherlands) and recombinant murine TNF- $\alpha$ (1000 U/ml; Innogenetics, Ghent, Belgium) were added in various combinations for $8-16 \mathrm{~h}$ incubations. In some of the experiments with primary beta cells IBMX was omitted from the medium immediately after exposure to the DNA-lipid complex. In two to three experiments where the activity of the iNOS wild-type promoter (piNOS1002luc) was evaluated after 8 or $16 \mathrm{~h}$ exposure to cytokines in the presence or absence of IBMX, there were no differences between the groups (data not shown). The concentrations of cytokines selected for the experiments were based on previous data from our group [8, 24, 28]. Luciferase activities were assayed with the Dual-Luciferase Reporter Assay System (Promega) in a TD-20/20 Luminometer (Turner Designs, Sunnyvale, Calif., USA). Values obtained with the promoterless vector pGL3Basic were about one light unit/5 $\mu \mathrm{l}$ (out of $50 \mu \mathrm{l}$ ) RINm5F cell extract and 0.6 light unit/20 $\mu$ l (out of $40 \mu \mathrm{l}$ ) beta-cell extract. Values for the test plasmids in unstimulated cell extracts were in the range of 10 to 20 light units (same volumes and cel- lular content as above). The values of the test plasmids were normalized for the luciferase activity value of the cotransfected control plasmid, pRL-CMV. Nitrite production was determined in culture medium using the Griess reaction [34]. Absorbance was measured at $546 \mathrm{~nm}$ and nitrite concentration was calculated from a standard curve of sodium nitrite. In RINm5F cell experiments, nitrite was measured in culture medium from cells transfected with piNOS-315luc and piNOS1514luc in the same experiment. The mean of the two values, which did not differ by more than $20 \%$, was considered as one independent value.

Reverse transcriptase-polymerase chain reaction (RT-PCR) analysis. $\operatorname{Poly}(\mathrm{A})+\mathrm{RNA}$ was isolated from $7.10^{4}$ to $10^{5}$ aggregated beta cells exposed to different cytokines for 8 or $16 \mathrm{~h}$ using oligo $(\mathrm{dT})_{25}$-coated polystyrene Dynabeads (Dynal, Oslo, Norway) according to the manufacturer's instructions. RTPCR was performed with the GeneAmp RNA PCR Kit (Perkin-Elmer) and amplified products were quantified as described previously [35]. Primers for iNOS were $5^{\prime}$-GACTGCACAGAATGTTCCAG (forward primer) and $5^{\prime}$ TGGCCAGATGTTCCTCTATT (reverse primer). Primers for glyceraldehyde 3-phosphate dehydrogenase (GAPDH) were 5 '-TCCCTCAAGATTGTCAGCAA (forward primer) and 5'-AGATCCACAACGGATACATT (reverse primer). The PCR for iNOS and GAPDH mRNAs detection was performed with 30 and 28 cycles, respectively. The reaction was linear for the number of cycles selected in the different amplifications (data not shown). Values for iNOS were corrected by GAPDH values. We have shown previously that GAPDH mRNA expression is not affected by beta-cell exposure to cytokines [36].

Statistical analysis. Results are given as means \pm SEM. Single comparisons were performed by Student's paired or unpaired $t$ test, whereas multiple comparisons were performed by analysis of variance (ANOVA).

\section{Results}

Delineation of the cytokine-responding regions of the rat iNOS promoter. IL- $1 \beta$, IFN- $\gamma$ and TNF- $\alpha$, alone or in various combinations, were tested for their ability to stimulate the activity of different constructs containing the rat iNOS promoter region from nucleotides -1514 to +132 and $5^{\prime}$ deletants linked to the luciferase reporter gene (Fig.1) transfected into RINm5F cells. The proximal region of the rat iNOS promoter contains a NF- $\kappa \mathrm{B}$ site at position -106 to $-97 \mathrm{bp}$, while the distal region (from -970 to -890 bp) contains a NF- $\kappa B$ site, a GAS and two adjacent ISREs (Fig.1). In unstimulated cells, all promoter constructs displayed a similar luciferase activity. 

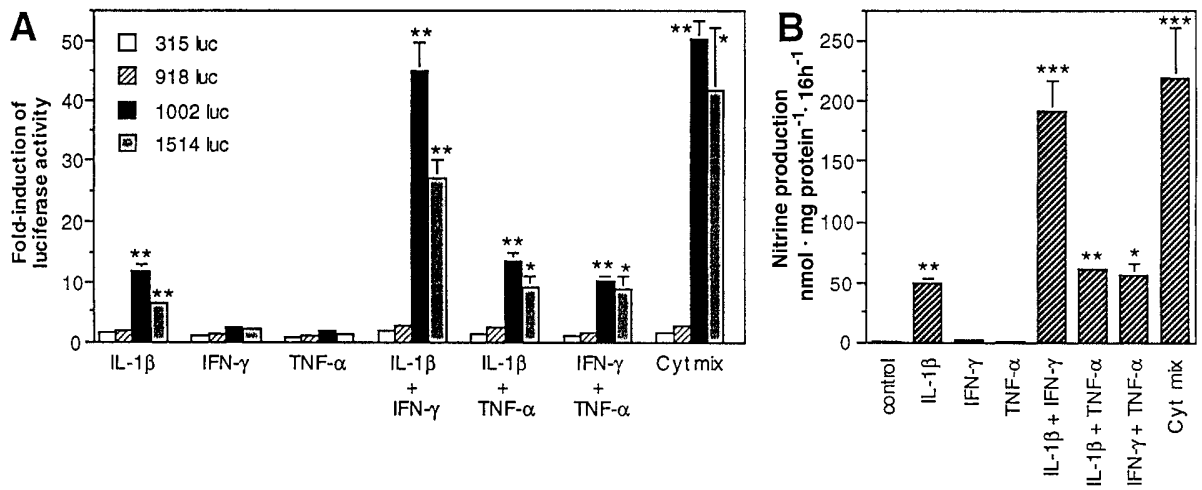

Fig. 2 A, B. iNOS promoter activity following cytokine treatment of RINm5F cells transfected with the $5^{\prime}$ deleted constructs of the iNOS promoter indicated in Figure 1. (A) Luciferase activity of the constructs after cytokine treatment for $16 \mathrm{~h}$ is expressed as a fold-induction of the activity of the same construct in control conditions (no cytokine added). Cyt mix is IL- $1 \beta+$ IFN- $\gamma+$ TNF- $\alpha$. Results are the means \pm SEM of 4 to 6 independent experiments. $* p<0.01$ and $* * p<0.001$ vs cells transfected with the piNOS-315luc construct and exposed to the same cytokines (ANOVA); (B) Nitrite production determined in the culture medium of the transfected cells. $* p<0.05, * * p<0.01$ and $* * * p<0.001$ vs control (no cytokines added) (ANOVA)

Both the constructs piNOS-315luc, containing only the proximal promoter region, and piNOS-918luc, extending up to and containing only the ISREs in the distal region, were induced less than 2.5 -fold by a $16 \mathrm{~h}$ exposure to the different combinations of cytokines (Fig. 2A). On the other hand, the two longest constructs retaining the distal region, piNOS-1514luc and piNOS-1002luc, responded to both IL- $1 \beta$ and the different combinations of cytokines with a marked (up to 50-fold) increase in promoter activity. The increase in activity of these two constructs was higher $(p<0.01)$ than that observed with both piNOS-315luc and piNOS-918luc. Neither IFN- $\gamma$ nor TNF- $\alpha$ alone induced a clear increase in promoter activity. The addition of TNF- $\alpha$ to IL- $1 \beta$ did not further increase the activity of any of the tested constructs. On the other hand, IFN- $\gamma$ potentiated by about fourfold the IL- $1 \beta$-induced activity of piNOS-1002luc and piNOS-1514luc ( $p<0.05$ vs IL- $1 \beta$ alone). A combination of the three cytokines did not further increase the promoter activity as compared with IL$1 \beta+$ IFN- $\gamma$, whereas IFN- $\gamma$ and TNF- $\alpha$ added together increased the activity to the same extent as IL- $1 \beta$ alone. Both IL- $1 \beta$ alone and the different cytokine combinations, induced an increase in medium nitrite accumulation similar to the pattern of cytokine-induced promoter activity (Fig. 2B). Combinations of IL- $1 \beta+$ IFN- $\gamma$ and IL- $1 \beta+$ IFN- $\gamma+$ TNF- $\alpha$ induced a four-fold higher medium nitrite accumulation than that observed in cells exposed to IL- $1 \beta$ alone $(p<0.001)$.
Transfection experiments were reproduced in FACS-purified pancreatic beta cells (Fig. 3). Due to the large number of beta cells required for these experiments, we tested only the constructs piNOS315 luc and piNOS-1002luc. The activity of piNOS315luc was induced less than three-fold by a mixture of the three cytokines (Fig. 3A). As observed in RINm5F cells, IL- $1 \beta$ alone, IL- $1 \beta+$ IFN- $\gamma$ or IL$1 \beta+$ IFN- $\gamma+$ TNF- $\alpha$ induced a clear increase (9 to 16 -fold) in the activity of piNOS-1002luc, which was significantly higher than the activity observed in the piNOS-315luc construct. The same cytokines induced a significant increase in medium nitrite accumulation, as compared with control beta cells (Fig. 3B). It is noteworthy that while IL- $1 \beta+$ IFN- $\gamma$, IL- $1 \beta+$ TNF$\alpha$ and IL- $1 \beta+$ IFN- $\gamma+$ TNF- $\alpha$ induced a 2 to 2.5 fold increase in beta-cell medium nitrite accumulation, as compared with nitrite production by cells exposed to IL-1 $\beta$ alone $(p<0.01)$ (Fig. 3B), there was not a similar increase in piNOS-1002luc activity following $16 \mathrm{~h}$ exposure to the cytokines (Fig. 3A). A similar lack of potentiating effects by IFN- $\gamma$ on promoter activity was observed when beta cells were exposed to IL- $1 \beta$ or IL- $1 \beta+$ IFN- $\gamma$ for a shorter period $(8 \mathrm{~h})$. Under these conditions IL- $1 \beta$ induced a tenfold increase in piNOS-1002luc activity and this was not further increased by the addition of IFN- $\gamma$ (data not shown). This lack of potentiating effect of IFN- $\gamma$ on primary beta-cell iNOS promoter activity (Fig. 3A) contrasts with the data obtained in RIN cells where the cytokine increased by four-fold the effect of IL- $1 \beta$ on both piNOS-1002luc activity (Fig. 2A) and medium nitrite accumulation (Fig. 2B).

One possible explanation for the higher NO production induced by IFN- $\gamma+$ IL- $1 \beta$ in beta cells, as compared with IL- $1 \beta$ alone, is that IFN- $\gamma$ increases iNOS mRNA expression by a post-transcriptional mechanism. To test this hypothesis, we analysed iNOS mRNA expression by RT-PCR. There was no iNOS expression in control beta cells (data not shown) but there was an increased and similar iNOS mRNA expression in beta cells incubated for $16 \mathrm{~h}$ with IL- $1 \beta$ alone, IL- $1 \beta+$ IFN- $\gamma$, IL- $1 \beta+$ TNF- $\alpha$ or with IL- $1 \beta+$ IFN- $\gamma+$ TNF- $\alpha$. Thus, the mRNA content (expressed in O.D. of iNOS/GAPDH; means \pm 

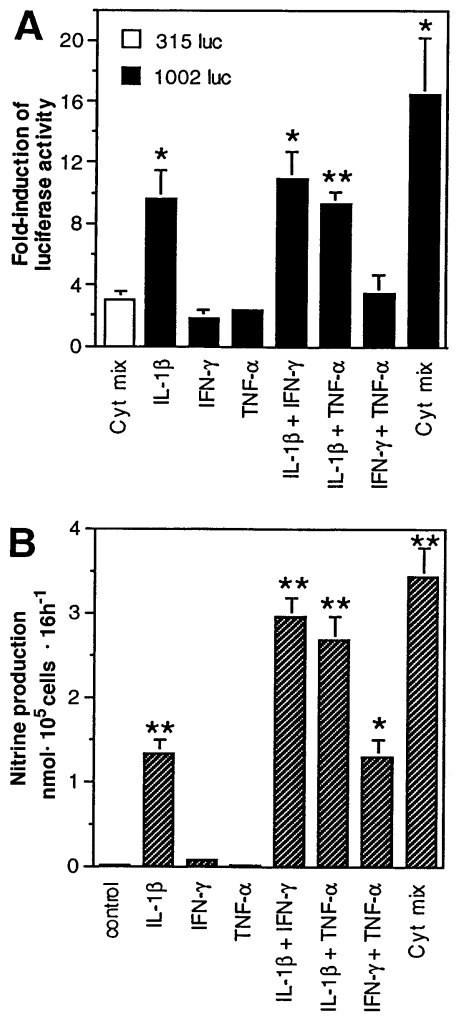

Fig. 3 A, B. iNOS promoter activity following cytokine treatment of primary beta cells transfected with the $5^{\prime}$ deleted constructs of the iNOS promoter indicated in Figure 1. (A) Luciferase activity of the constructs after cytokine treatment for $16 \mathrm{~h}$ is expressed as a fold-induction of the activity of the same construct in control conditions (no cytokine added). Cyt mix is IL- $1 \beta+$ IFN- $\gamma+$ TNF- $\alpha$. Results are the means \pm SEM of 3 to 4 independent experiments (except for TNF- $\alpha$ treatment, two experiments). $* p<0.05$ and $* * p<0.01$ vs cells transfected with the piNOS-315luc construct and exposed to 3 cytokines (unpaired $t$ test). (B) Nitrite production determined in the culture medium of the transfected cells. ${ }^{*} p<0.01$ and $* * p<0.001$ vs control (no cytokines added) (ANOVA)

SEM of three separate experiments) for beta cells exposed to IL- $1 \beta+$ IFN- $\gamma$, IL- $1 \beta+$ TNF- $\alpha$ and IL- $1 \beta+$ IFN- $\gamma+$ TNF- $\alpha$ was respectively $102 \pm 16 \%, 97 \pm$ $16 \%$ and $129 \pm 19 \%$ of the value observed following IL-1 $\beta$ alone treatment. A cytokine-exposure time of $8 \mathrm{~h}$ produced the same results, i.e. a similar increase in iNOS mRNA expression following beta-cell exposure to IL- $1 \beta$ alone or to combinations of cytokines (data not shown). These results agree well with the observations on cytokine-induced promoter activity (Fig. 3A), and indicate that IFN- $\gamma$ potentiating effects on IL- $1 \beta$-induced NO production by primary rat beta cells are effected at steps downstream of iNOS mRNA expression.

The induction of iNOS promoter activity by cytokines is probably specific for the beta cells, since the activity of piNOS-1002luc transfected into primary alpha cells was barely induced by IL- $1 \beta+$ IFN- $\gamma$ (1.4-fold increase, as compared with activity in cells
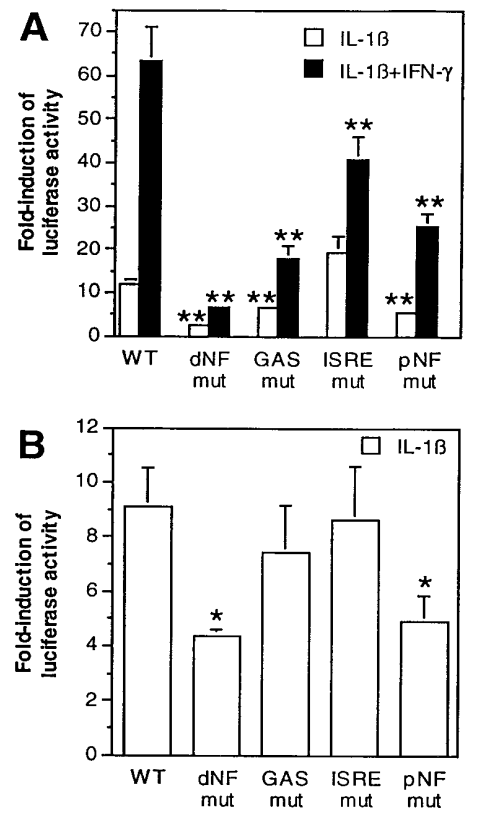

Fig. 4. Effect of site-directed mutations on iNOS promoter activity following IL- $1 \beta$ and IL- $\beta+$ IFN- $\gamma$ treatment in RINm5F cells $(\mathbf{A})$ or in primary beta cells $(\mathbf{B})$. Cells were transfected with the piNOS-1002luc (wild-type, WT) shown in Figure 1 or with the same construct but mutated either in the distal NF- $\kappa B$ site (dNFmut), the GAS (GASmut), the distal ISRE (ISREmut) or in the proximal NF- $\kappa \mathrm{B}$ site (pNFmut). Luciferase activity of the constructs after cytokine treatment for $16 \mathrm{~h}$ (RINm5F cells) or $8 \mathrm{~h}$ (beta cells) is expressed as a fold-induction of the activity of the same construct in control conditions (no cytokine added). Results are the means \pm SEM of 6 independent experiments (RINm5F cells) or 3 to 4 experiments (beta cells). $* p<0.05, * * p<0.01$ vs induction of WT activity following exposure to similar cytokine(s), by paired $t$ test

not exposed to cytokines; mean of two similar experiments). This confirms previous results that alpha cells do not express iNOS when exposed to cytokines [37] (Flodström, Chen, Smismans, Schuit, Pipeleers and Eizirik, unpublished observations).

Role of the cis-acting elements in the induction of $i N O S$ promoter by $I L-1 \beta$ and IFN- $\gamma$. To further investigate the role of individual DNA-binding sites for different transcription factors in iNOS expression, we constructed mutants from piNOS-1002luc in which either the distal NF- $\kappa B$ site (piNOS-dNFmut), the proximal NF- $\kappa B$ site (piNOS-pNFmut), the GAS (piNOS-GASmut) or the distal ISRE (piNOS-ISRE mutant; named ISREa in Fig. 1), were inactivated. Disruption of the distal ISRE has been shown to be sufficient to affect promoter activity in macrophages and in vascular smooth muscle cells $[20,21]$. These constructs were transfected into RINm5F cells and the induction of their activity after IL- $1 \beta$ or IL- $1 \beta+$ IFN- $\gamma$ treatment was compared with that observed with the wild-type construct (piNOS-1002luc). As shown in Fig.4A, inactivation of either the distal 
$\mathrm{NF}-\kappa \mathrm{B}$ site, the proximal NF- $\kappa \mathrm{B}$ site or the GAS reduced by $50-80 \%$ the IL- $1 \beta$-induced promoter activity. Disruption of the distal ISRE did not reduce the effect of IL- $1 \beta$. Instead, there was a trend $(p=0.052)$ for a higher stimulation by IL-1 $\beta$ (Fig. 4A). Mutations in the distal and proximal NF- $\mathrm{\kappa B}$ sites, the GAS and the distal ISRE all impaired promoter activation by IL- $1 \beta+$ IFN $-\gamma$. Mutations in the GAS and ISRE sites decreased by more than $50 \%$ the IFN- $\gamma$ potentiating effect, indicating that these two binding sites are important for the IFN- $\gamma$ signal transduction resulting in iNOS expression. On the other hand, mutations in the NF- $\kappa \mathrm{B}$ binding sites severely decreased the effects of IL- $1 \beta$ alone or IL- $1 \beta+$ IFN- $\gamma$, confirming a role for NF- $\kappa \mathrm{B}$ activation in IL- $1 \beta$ signal transduction.

Transfection experiments with the site-mutated constructs were reproduced in primary beta cells (Fig. 4B). In these experiments the cells were cultured in the absence of IBMX to avoid potential interferences with the luciferase activities of the different constructs. Inactivation of the distal and proximal $\mathrm{NF}-\kappa \mathrm{B}$ sites reduced the IL- $1 \beta$ induction of promoter activity by 52 and $46 \%$, respectively, whereas GAS and ISRE mutations failed to affect promoter activity. Similar results were obtained when the cells were treated with IL-1 $\beta+$ IFN- $\gamma$ (data not shown).

\section{Discussion}

We have delineated the elements in the rat iNOS promoter conferring cytokine-inducibility in insulinproducing cells. The data indicate that a distal region of the promoter extending up to position -1002 and containing two NF- $\kappa \mathrm{B}$ sites, a GAS and two ISREs, is required for IL- $1 \beta$ induction and IFN- $\gamma$ potentiation in an insulinoma cell line, RINm5F. Nitrite production induced by the different combinations of cytokines mostly reflected promoter induced activity (present data) and iNOS mRNA expression [38], suggesting that iNOS activity is regulated mainly at the transcriptional level in these cells. Site-directed mutagenesis showed that both the distal and proximal NF- $\kappa \mathrm{B}$ sites are necessary for IL- $1 \beta$ induction. Mutation in the distal site reduced the promoter induction by $80 \%$, whereas mutation in the proximal site reduced this induction by $50 \%$. Thus, the distal $\mathrm{NF}-\kappa \mathrm{B}$ site appears to be more important for iNOS promoter activity in RINm5F cells. Similar observations were made in a study with the mouse promoter transfected into rat vascular smooth muscle cells exposed to IL- $1 \beta+$ IFN- $\gamma+$ TNF- $\alpha$ [18]. On the other hand, mutations in the proximal NF- $\kappa \mathrm{B}$ site had a drastic effect on iNOS promoter activity in mouse macrophages exposed to LPS [17]. The fact that different NF- $\kappa B$ sites are involved in IL- $1 \beta$ and LPS induction can not be attributed to a difference be- tween rat and mouse promoters, since the studies in vascular smooth muscle cells were performed with the mouse promoter [18]. Rather, it is conceivable that IL- $1 \beta$ and LPS activate different proteins of the NF- $\kappa \mathrm{B} / \mathrm{Rel}$ family, affecting the NF- $\kappa \mathrm{B}$ binding sites differently [18]. Interaction of transcription factors with an octamer-binding site in the proximity of the proximal NF- $\mathrm{KB}$ site could be necessary for iNOS expression [39]. Thus, differences in iNOS regulation by IL- $1 \beta$ and LPS could also be related to the ability of activating additional transcription factors which will co-operate with NF- $\mathrm{BB}$. Our results showed that mutation in the GAS impaired IL- $1 \beta$ induced promoter activity by nearly $50 \%$. GAS binds homodimers of the Stat1 a transcription factor induced by IFN- $\gamma$ [40], but Stat $1 \alpha$ may also be induced in response to LPS in macrophages, binding to the GAS of the iNOS promoter [19]. It is thus conceivable that IL- $1 \beta$ induces both NF- $\kappa \mathrm{B}$ [22-26] and Stat $1 \alpha$ in insulin-producing cells. In line with this hypothesis, we observed that IL- $1 \beta$ induces the expression of IRF-1, another Stat $1 \alpha$-responsive gene, in RINm5F cells [28]. We believe this is the first indication that GAS plays a direct a role for cytokine-induced iNOS expression in insulin-producing cells.

Mutations in either the GAS, ISRE or distal NF$\kappa \mathrm{B}$ impaired the potentiation by IFN- $\gamma$ of IL- $1 \beta$-induced iNOS promoter activity. This suggests that both a basal NF- $\kappa \mathrm{B}$ stimulation, as induced by IL$1 \beta$, and IFN- $\gamma$-induced Stat $1 \alpha$ and IRF- 1 are required for full iNOS expression in RINm5F cells. Note that IFN- $\gamma$ does not stimulate NF- $\kappa B$ activation in insulin-producing cells [28], emphasizing an action of the cytokine via Stat $1 \alpha$ and IRF-1. Stat $1 \alpha$ could contribute to iNOS expression by both a direct role, through binding to the GAS (see above), and by an indirect role, via induction of the transcription factor IRF-1 [41]. Indeed, IFN- $\gamma$ produces a marked increase in IRF-1 expression in RINm5F cells [28]. These observations could be relevant to the mechanisms involved in iNOS induction in human pancreatic islets. Thus, in these cells neither IL- $1 \beta$ nor IFN- $\gamma$ alone induce iNOS expression but a combination of the two cytokines leads to NO production [7, 8, 28]. Moreover, $\mathrm{NF}-\kappa \mathrm{B}$ activation alone is not sufficient for iNOS expression in human islets [26] and IFN- $\gamma$-induced IRF-1 expression precedes iNOS activation [28], suggesting a role for the IFN- $\gamma$-induced transcription factors discussed above.

Transfection experiments with different iNOS constructs in FACS-purified primary beta cells showed that the distal region of the iNOS promoter is necessary for IL- $1 \beta$ induction in these cells. Subsequent mutagenesis experiments indicated that IL- $1 \beta$ effects are mediated by both the distal and proximal $\mathrm{NF}-\kappa \mathrm{B}$ sites. In rat beta cells IFN- $\gamma$ failed to potentiate both IL- $1 \beta$-induced iNOS promoter activity and 
mRNA expression and mutations of the GAS and ISRE binding sites had no effect on IL- $1 \beta$ or IL$1 \beta+$ IFN- $\gamma$ induction of the iNOS promoter. Previous data from our group showed that IFN- $\gamma$ induces a much lower increase in IRF-1 protein expression in rat islets, as compared with RIN m5F cells and human islets [28], which could help to explain this decreased effect of IFN- $\gamma$ on rat beta cells. It is noteworthy that in spite of the lack of IFN- $\gamma$ potentiating effects on iNOS promoter activity and iNOS mRNA expression (see above), there was a two-fold increase in nitrite production in beta cells exposed to IL- $1 \beta+$ IFN- $\gamma$, as compared to cells exposed to IL- $1 \beta$ alone. Furthermore, exposure of rat beta cells to IL$1 \beta+$ IFN- $\gamma$ increases the number of beta cells expressing iNOS protein, as compared with cells exposed to IL-1 $\beta$ only [5]. This raises the possibility that, as suggested for mouse macrophages [42], IFN$\gamma$ increases IL- $1 \beta$-induced NO production in rat beta cells by affecting iNOS protein translation or stability or both.

Nitric oxide may contribute to beta-cell dysfunction and damage in early Type I diabetes mellitus [3-5]. A better understanding of the molecular regulation of iNOS in insulin-producing cells can help to define potential targets for genetical intervention in order to prevent iNOS expression inside and around the beta cells during insulitis. Our observations that binding sites for NF- $\kappa B$, Stat $1 \alpha$ and IRF-1 are required for iNOS expression in insulin-producing cells suggests that it could be of interest to test whether modulation of these transcription factors affect the natural history of experimental autoimmune diabetes in rodents.

Acknowledgements. The excellent technical assistance of E. Verheugen and the personnel involved in rat islet isolation and beta-cell FACS sorting is gratefully acknowledged. We thank Professor D. Pipeleers for helpful discussions and for generously providing access to purified rat beta cells. This work was supported by grants from the Juvenile Diabetes Foundation International, the Flemish National Research Foundation (FWO Grant No. G.0376.96), the Belgium National Ministry of Science (IUAP - DWTC 11) and by a Shared Cost Action in Medical and Health Research of the European Community.

\section{References}

1. Rabinovitch A (1993) Roles of cytokines in IDDM pathogenesis and islet $\beta$-cell destruction. Diabetes Rev 1: 215-240

2. Mandrup-Poulsen T (1996) The role of interleukin-1 in the pathogenesis of IDDM. Diabetologia 39: 1005-1029

3. Kolb H, Kolb-Bachofen V (1992) Type 1 (insulin-dependent) diabetes mellitus and nitric oxide. Diabetologia 35: 796-797

4. Corbett JA, McDaniel ML (1992) Does nitric oxide mediate autoimmune destruction of $\beta$-cells? Possible therapeutic interventions in IDDM. Diabetes 41: 897-903
5. Eizirik DL, Pavlovic D (1997) Is there a role for nitric oxide in $\beta$-cell dysfunction and damage in IDDM? Diabetes Metab Rev 13: 293-308

6. Takamura T, Kato I, Kimura N et al. (1998) Transgenic mice overexpressing Type 2 nitric-oxide synthase in pancreatic $\beta$ cells develop insulin-dependent diabetes without insulitis. J Biol Chem 273: 2493-2496

7. Corbett JA, Sweetland MA, Wang JL, Lancaster JJ, McDaniel ML (1993) Nitric oxide mediates cytokine-induced inhibition of insulin secretion by human islets of Langerhans. Proc Natl Acad Sci USA 90: 1731-1735

8. Eizirik DL, Sandler S, Welsh N et al. (1994) Cytokines suppress human islet function irrespective of their effects on nitric oxide generation. J Clin Invest 93: 1968-1974

9. Rabinovitch A, Suarez-Pinzon WL, Strynadka K et al. (1994) Human pancreatic islet $\beta$-cell destruction by cytokines is independent of nitric oxide production. J Clin Endocrinol Metab 79: 1058-1062

10. Eizirik DL, Delaney CA, Green MH et al. (1996) Nitric oxide donors decrease the function and survival of human pancreatic islets. Mol Cell Endocrinol 118: 71-83

11. Delaney CA, Tyrberg B, Bouwens L, Vaghef H, Hellman B, Eizirik DL (1996) Sensitivity of human pancreatic islets to peroxynitrite-induced cell dysfunction and death. FEBS Lett 394: 300-306

12. Eizirik DL, Flodström M, Karlsen AE, Welsh N (1996) The harmony of the spheres: inducible nitric oxide synthase and related genes in pancreatic beta cells. Diabetologia 39: $875-890$

13. Fostermann U, Gath I, Schwarz P, Closs EI, Kleinert H (1995) Isoforms of nitric oxide synthase: properties, cellular distribution and expressional control. Biochem Pharmacol 50: 1321-1332

14. Xie QW, Whisnant R, Nathan C (1993) Promoter of the mouse gene encoding calcium-independent nitric oxide synthase confers inductibility by interferon $\gamma$ and bacterial lipopolysaccharide. J Exp Med 177: 1779-1784

15. Eberhardt W, Kunz D, Hummel R, Pfeilshifter J (1996) Molecular cloning of the rat inducible nitric oxide synthase gene promoter. Biochem Biophys Res Commun 223: $752-756$

16. Xie QW, Kashiwabara Y, Nathan C (1994) Role of transcription factor NF- $\kappa \mathrm{B} / \mathrm{Rel}$ in induction of nitric oxide synthase. J Biol Chem 269: 4705-4708

17. Kim YM, Lee BS, Yi KY, Paik SG (1997) Upstream NF-кB site is required for the maximal expression of mouse inducible nitric oxide synthase gene in interferon- $\gamma$ plus lipopolysaccharide-induced RAW 264.7 macrophages. Biochem Biophys Res Commun 236: 655-660

18. Spink J, Cohen J, Evans TJ (1995) The cytokine responsive vascular smooth muscle cell enhancer of inductible nitric oxide synthase. J Biol Chem 270: 29541-29547

19. Gao J, Morrison DC, Parmely TJ, Russell SW, Murphy WJ (1997) An interferon- $\gamma$-activated site (GAS) is necessary for full expression of the mouse $i N O S$ gene in response to interferon- $\gamma$ and lipopolysaccharide. J Biol Chem 272: 1226-1230

20. Martin E, Nathan C, Xie QW (1994) Role of interferon regulatory factor 1 in induction of nitric oxide synthase. $J$ Exp Med 180: 977-984

21. Spink J, Evans T (1997) Binding of the transcription factor interferon regulatory factor- 1 to the inductible nitric-oxide synthase promoter. J Biol Chem 272: 24417-24425

22. Kamijo R, Harada H, Matsuyama T et al. (1994) Requirement for transcription factor IRF-1 in NO synthase induction in macrophages. Science 263: 1612-1615 
23. Saldeen J, Welsh N (1994) Interleukin- $1 \beta$ induced activation of NF- $\kappa \mathrm{B}$ in insulin producing RINm5F cells is prevented by the protease inhibitor Na-p-tosyl-L-lysine chloromethylketone. Biochem Biophys Res Commun 203: 149-155

24. Bedoya F, Flodström M, Eizirik DL (1995) Pyrrolidine dithiocarbamate prevents IL-1-induced nitric oxide synthase mRNA, but not superoxide dismutase mRNA, in insulin-producing cells. Biochem Biophys Res Commun 210: 816-822

25. Kwon G, Corbett JA, Rodi CP, Sullivan P, McDaniel ML (1995) Interleukin- $\beta$-induced nitric oxide synthase by rat pancreatic islets: evidence for the involvement of nuclear factor $\mathrm{\kappa B}$ in the signaling mechanism. Endocrinology 136: 4790-4795

26. Flodström M, Welsh N, Eizirik DL(1996) Cytokines activate the nuclear factor $\kappa \mathrm{B}(\mathrm{NF}-\mathrm{\kappa B})$ and induce nitric oxide production in human pancreatic islets. FEBS Lett 385: 4-6

27. Akabane A, Kato I, Takasawa S et al. (1995) Nicotinamide inhibits IRF- 1 mRNA induction and prevents IL- $1 \beta$-induced nitric oxide synthase expression in pancreatic $\beta$-cells. Biochem Biophys Res Commun 215: 524-530

28. Flodström M, Eizirik DL (1997) Interferon- $\gamma$-induced interferon regulatory factor-1 (IRF-1) expression in rodent and human islet cells precedes nitric oxide production. Endocrinology 138: 2747-2753

29. Pipeleers DG, in't Veld PA, Van De Winkel M, Maes E, Schuit FC, Gepts W (1985) A new in vitro model for the study of pancreatic A and B cells. Endocrinology 117: 806-816

30. Ling Z, Hannaert JC, Pipeleers D (1994) Effect of nutrients, hormones and serum on survival of rat islet $\beta$ cells in culture. Diabetologia 37: 15-21

31. Schuit FC, Pipeleers DG (1985) Regulation of adenosine 3', 5 '-monophosphate levels in the pancreatic B cell. Endocrinology 117: 834-840

32. Ausubel FM, Brent R, Kingston RE et al. (1994) Current Protocols in Molecular Biology. Wiley \& Sons. New York, pp 2.2.1-2.2.3
33. Coolidge CJ, Patton JG (1995) Run-around PCR: a novel way to create duplications using polymerase chain reaction. BioTechniques 18: 763-764

34. Green LC, Wagner DA, Goglowski J, Skipper PL, Wishnok JS, Tannenbaum SR (1982) Analysis of nitrate, nitrite, and $\left[{ }^{15} \mathrm{~N}\right]$ nitrate in biological fluids. Anal Biochem 126: 131-138

35. Ling Z, Chen MC, Smismans A et al. (1998) Intercellular differences in interleukin- $1 \beta$-induced suppression of insulin synthesis and stimulation of non-insulin protein synthesis by rat pancreatic $\beta$ cells. Endocrinology 139: 1540-1545

36. Eizirik DL, Björklund A, Cagliero E (1993) Genotoxic agents increase expression of growth arrest and DNA damage-inducible genes gadd 153 and gadd 45 in rat pancreatic islets. Diabetes 42: 738-745

37. Corbett JA, McDaniel ML (1995) Intraislet release of interleukin-1 inhibits beta-cell function by inducing $\beta$-cell expression of inducible nitric oxide synthase. J Exp Med 181: 559-568

38. Cetkovic-Cvrlje M, Eizirik DL (1994) TNF- $\alpha$ and INF- $\gamma$ potentiate the deleterious effect of IL- $1 \beta$ on mouse pancreatic islets mainly via generation of nitric oxide. Cytokine 6 : 399-406

39. Xie QW (1997) A novel lipopolysaccharide-response element contributes to induction of nitric oxide synthase. J Biol Chem 272: 14867-14872

40. Leaman DW, Leung S, Li X, Stark GR (1996) Regulation of STAT-dependent pathways by growth factors and cytokines. FASEB J 10: 1578-1588

41. Rein T, Muller M, Zorbas H (1994) In vivo footprinting of the IRF-1 promoter: inducible occupation of a GAS element next to a persistent structural alteration of the DNA. Nucleic Acids Res 22: 3033-3037

42. Salkowski CA, Barber SA, Detore GR, Vogel SN (1996) Differential dysregulation of nitric oxide production in macrophages with targeted disruptions in IFN regulatory factor-1 and -2 genes. J Immunol 156: 3107-3110 